\title{
Lake-level variations and tides in Lago Argentino, Patagonia: insights from pressure tide gauge records
}

\author{
Andreas RICHTER,,${ }^{1,2,3 *}$ Eric MARDERWALD,${ }^{1,2}$ José Luis HORMAECHEA, ${ }^{4}$ Luciano MENDOZA,,${ }^{1,2}$ Raúl PERDOMO, ${ }^{1}$ \\ Gerardo CONNON, ${ }^{4}$ Mirko SCHEINERT, ${ }^{3}$ Martin HORWATH, ${ }^{3}$ Reinhard DIETRICH ${ }^{3}$ \\ ${ }^{1}$ Universidad Nacional de La Plata, Facultad de Ciencias Astronómicas y Geofísicas, Paseo del Bosque s/n, 1900 La Plata, Argentina; \\ ${ }^{2}$ Consejo Nacional de Investigaciones Científicas y Técnicas, Av. Rivadavia 1917, C1033AAJ Ciudad Autónoma de Buenos Aires, \\ Argentina; ${ }^{3}$ Technische Universität Dresden, Institut für Planetare Geodäsie, Helmholtzstraße 10, D-01069 Dresden, Germany; \\ ${ }^{4}$ Estación Astronómica Río Grande, Acceso Aeropuerto, V9420EAR Rio Grande, Tierra del Fuego, Argentina \\ *Corresponding author: andreas.richter@tu-dresden.de
}

\begin{abstract}
Based on precise pressure tide gauge observations lake-level records are derived for two sites in Lago Argentino, southern Patagonia, of 2.5 and 1 years of duration. Applying the tools of time series analysis, the principal processes affecting the lake level are identified and quantified. Lake-level changes reflecting variations in lake volume are dominated by a seasonal cycle of $1.2 \mathrm{~m}$ in amplitude. Lakevolume changes occur in addition with a daily period in response to melt water influx from surrounding glaciers. Sporadic lake-volume jumps are caused by bursting of the ice dam of Perito Moreno glacier. Water movements in Lago Argentino are dominated by surface seiches reaching $20 \mathrm{~cm}$ in amplitude. Lake tides reach a maximum amplitude of $3 \mathrm{~mm}$. The comparison of the tidal signal extracted from the lake-level observations with a model composed of the contributions of body tide and ocean tidal loading indicates a phase shift of $23^{\circ}$ which is most likely explained by an 1 hour phase lag of global ocean tide models in the region of the highly fragmented Pacific coast. The comparison of the obtained results with those of a previous study of Lago Fagnano, Tierra del Fuego, allows to relate differences in the hydrological and hydrodynamic processes between both lakes to morphological properties. This leads to a tentative prediction of the lake-level variability to be expected from other great Patagonian lakes. The presented geodetic results shall serve as a starting point for a detailed limnological investigation of these aquatic ecosystems.
\end{abstract}

Key words: Hydrodynamics; lake level; surface seiches; tide gange; Patagonia.

Received: February 2015. Accepted: July 2015.

\section{INTRODUCTION}

Lago Argentino is the largest lake completely contained in Argentine territory. At the same time, it is the second largest of the Patagonian lakes (after Lago Buenos Aires/General Carrera shared with Chile) and one of the six largest lakes in South America (Strelin et al., 2014). Nevertheless, surprisingly little results of limnological and hydrodynamic research on this lake is found in the literature (Quirós et al., 1988; Diaz et al., 2007; Pasquini and Depetris 2011).

Lago Argentino is situated in the province of Santa Cruz in the southern part of Patagonia, at the foot of the eastern flank of the Andean Cordillera, between 50.0$50.5^{\circ} \mathrm{S}$ and $72.0-73.3^{\circ} \mathrm{W}$ (Fig. 1a). This lake combines in a unique manner two different natures. This becomes evident by one look on the map (Fig. 1b): the western half of the lake is composed of narrow, deep glacier valleys that branch out deep into the Andean high-mountain relief towards the glaciers descending from the Southern Patagonian Icefield and calving into the lake. This setting shall be termed the glacier-valley environment. The eastern half of the lake, in contrast, is formed by a broad, regular and, probably, shallow basin that extends among flat, terraced plateaus. This morphological character is referred to as Andean terminal lake (Quirós et al., 1988). This abrupt morphological change is accompanied by strong gradients in meteorological parameters, vegetation and geological structure. The regional climate, characterized as summercool, winter mild wind climate (Weischet, 1996), is determined by strong westerly winds. While the Pacific flank and the crest of the Patagonian Andes receive abundant precipitation of up to $10 \mathrm{~m}$ yearly (Casassa and Rivera, 1999), the precipitation rate drops rapidly towards east to $200 \mathrm{~mm}$ at El Calafate (Strelin et al., 2014). In the glacier-valley environment the lake shores are steep and covered by dense Nothafagus forest. In the terminal-lake environment the shore is made of flat beaches amidst the Patagonian steppe of meagre scrub vegetation. Geologically, the west-east extend of Lago Argentino marks the transition from the Andean orogen, through the Patagonian fold-and-thrust belt, into the Magallanes retroarc foreland basin (Menichetti et al., 2008; Ghiglione et al.; 2009, Fosdick et al., 2011).

The peculiar present-day morphology of the lake is a 
result of repeated glaciations since the Miocene/Pliocene transition (Rabassa et al., 2005). While the western glacier valleys were carved deeply into the Andean bedrock by repeatedly advancing and receding glaciers, the recent eastern lake shore is made of Pleistocene terminal moraines deposited shortly after the Last Glacial Maximum (Strelin et al., 2014). After a retreat deep into the Andes, a late- Pleistocene glacial readvance termed Punta Bandera stadial (Strelin et al., 2014) left a moraine complex just at the boundary between the glacier-valley and the terminal-lake environments. Today the Northern and
Southern Patagonian Icefields, the largest extra-polar ice mass on the southern hemisphere, represent the receding remnants of these vast glaciations.

Lago Argentino shares its dual morphological character, its geological, climatic and vegetation setting as well as its glacial history with a whole chain of lakes aligned from north to south along the eastern flank of the Patagonian Andes (Pasquini et al., 2008). Attention will be paid here to the great Patagonian lakes including Lago Buenos Aires/General Carrera, Lago San Martín/O’Higgins, Lago Viedma and Lago Fagnano in Tierra del Fuego (Fig. 1a).

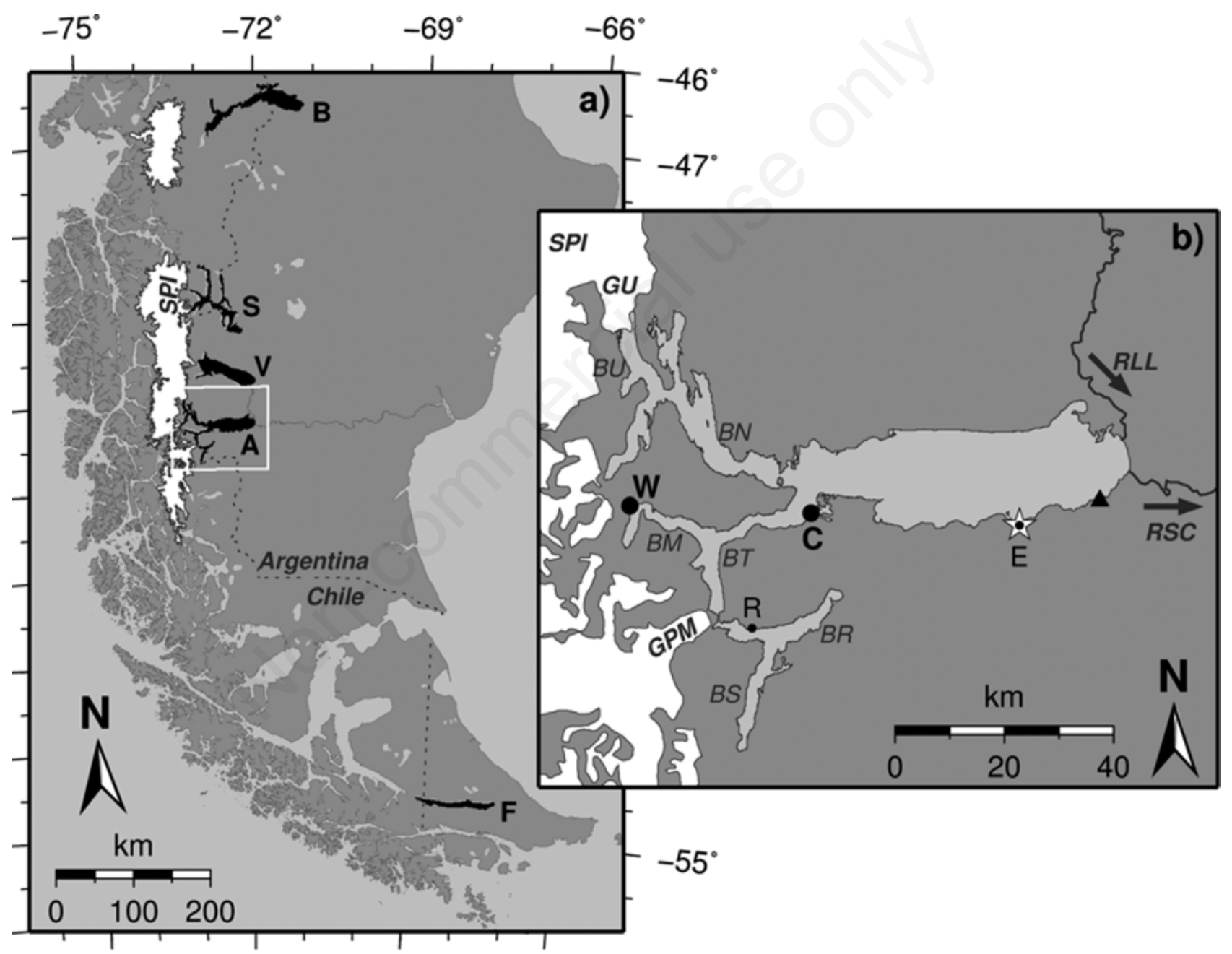

Fig. 1. a) Map of southern Patagonia, southernmost South America. Highlighted in black are the great Patagonian lakes mentioned in the text: Lago Buenos Aires/General Carrera (B), Lago San Martín/O'Higgins (S), Lago Viedma (V), Lago Argentino (A) and Lago Fagnano (F). White patches depict the Northern and Southern Patagonian Icefields (SPI). Dashed line, national border between Argentina and Chile; white box, area of the map in Fig. 1b. b) Map of the Lago Argentina area. Big black dots mark the pressure tide gauge sites $\mathrm{C}$ and W; small black dots, tide gauge sites R (Brazo Rico) and E (El Calafate) for which lake-level data from BDHI (2015) were used; black triangle, meteorological station of Servicio Meteorológico Nacional at El Calafate airport; white star, El Calafate town; grey lines, rivers Río La Leona (RLL) and Río Santa Cruz (RSC). Light grey, Lago Argentino; white area, Southern Patagonian Icefield (SPI) and glaciers (GU, Upsala glacier; GPM, Perito Moreno glacier); BU, Brazo Upsala; BN, Brazo Norte; BM, Brazo Mayo; BT, Brazo de los Tempanos; BR, Brazo Rico; BS, Brazo Sur. 
Roughly of comparable size, each of these lakes is composed in a certain proportion of the two contrasting lake environments. However, none of these lakes exhibits the stunning balance between glacier valleys and terminal-lake setting characteristic for Lago Argentino. While Lago San Martín/O'Higgins pertains almost completely to the glacier-valley environment, save for the small Brazo Chacabuco at its south-eastern tip, Lago Viedma is clearly dominated by the terminal-lake environment. Lago Fagnano stands out somewhat from this morphological systematisation because it owes its formation, in addition to the repeated glaciations, to tectonic processes along the Magallanes-Fagnano fault zone (Lodolo et al., 2003). Crustal deformation along the major transform fault representing the boundary between the South American and Scotia tectonic plates led to the opening of pull-apart basins which today host the Fagnano lake (Mendoza et al., 2011; 2015). This tectonic component of its formation is responsible for the exceptionally regular geometry of the basin and its large depth compared to the terminal-lake environment. Lagos Argentino, Viedma and San Martín/O’Higgins are fed directly by calving glaciers, whereas Lagos Buenos Aires/General Carrera and Fagnano are influenced by seasonal snow accumulation in the surrounding mountains and more distant glacial systems (Northern Patagonian Icefield and Cordillera Darwin, respectively). The different degrees of glacial influence on the lakes become evident in their colour on satellite images.

The western part of Lago Argentino pertains to the Los Glaciares National Park declared a world natural heritage by UNESCO. It is a famous tourist destination, to a large extent due to the access to large glaciers amidst lush vegetation and the recurrent natural spectacle of the bursting ice dam of Perito Moreno glacier (Pasquini and Depetris, 2011). The lake reaches its maximum extent of $99.8 \mathrm{~km}$ in approximate east-west direction. The surface area of the lake amounts to $1330 \mathrm{~km}^{2}$. The lake level is situated on a mean elevation of $178 \mathrm{~m}$ (Busch, 2014) above the EGM2008 geoid model (Pavlis et al., 2012). Quirós et al. (1988) state a mean depth of $150 \mathrm{~m}$ for this lake; however, no further details on the soundings are given. Skvarca and De Angelis (2001) determined lake depths exceeding 700 $\mathrm{m}$ in a local survey in Brazo Upsala, close to the calving front of Upsala glacier, which are recognized as the lake's maximum depth. Pressure tide gauge records from different locations in Lago Fagnano, Tierra del Fuego, and their systematic analysis have revealed first insights, quantitative descriptions and causal relationships of the main hydrological and hydrodynamic processes affecting lakelevel variations of this lake (Richter et al., 2010). That study demonstrated the potential of the lake-level observations as indicator for different environmental processes and for an observational validation of models of ocean tidal loading (Richter et al., 2009).
This work presents the results and interpretation of pressure tide gauge observations at two sites in Lago Argentino. Making use of a geodetic approach, it aims at a first and basic description of the principal processes reflected in the lake-level variations in this lake. A comparison of the results with those obtained in Lago Fagnano shall help to unveil principles in the similarities and differences in the manifestation of these processes in both lakes and thus provide a basis for a prediction of the lakelevel variability in the other great Patagonian lakes. These insights are fundamental for the understanding of energy and mass flux, chemical and biological processes and shall provide a stimulus and starting point for a detailed limnological investigation of these aquatic ecosystems. In addition to the promise these pristine lakes hold for limnological research, the knowledge of their lake-level variations on a wide range of time scales is particularly relevant for geophysical, geodynamic, geomorphological (Strelin et al., 2014), glaciological (Naruse and Skvarca, 2000; Kobayashi et al., 2001; Sugiyama et al., 2011), hydrological (Pasquini et al. 2008), and geodetic (Lange et al., 2014) research in the region of the Patagonian Icefields. They may help to understand the interactions between glaciers, lakes and solid earth in an environment affected by ongoing climate change, rapid changes in ice mass and intense glacial-isostatic adjustment. Lake tides, although small in amplitude, are especially interesting in this area because their observation may provide regional constraints for elastic earth models, which are a prerequisite for the modelling of crustal deformation due to the solid earth response to present-day ice-mass changes (Dietrich et al., 2010; Lange et al., 2014).

\section{METHODS}

\section{Lake-level observations}

At two sites in Lago Argentino pressure tide gauges were operated to record lake-level variations. The first site, henceforth referred to as site $\mathrm{C}$, is located at Punta Bandera port, close to the geometrical centre of the lake area. The second site, site $\mathrm{W}$, is located in Bahía Toro, a small bay in the NW corner of Brazo Mayo (Fig. 1b). At both sites Aanderaa WLR 7 water level recorders were deployed at the lake bottom. At site $\mathrm{C}$, three consecutive records were retrieved extending altogether from December 2011 to August 2014 with sampling intervals between 5 and $15 \mathrm{~min}$. The tide-gauge record obtained at site $\mathrm{W}$ extends from February 2012 to February 2013 with a sampling interval of $10 \mathrm{~min}$. Details of the tide-gauge records are given in Tab. 1.

These high-resolution records are complemented by water level data of the Argentine National Hydrometeorological Network retrieved from the Base de Datos Hidrológica Integrada of the Subsecretaría de Recursos 
Hídricos (BDHI, 2015). From this data base we use lake level data from El Calafate (Lago Argentino, site E), Brazo Rico (Lago Argentino, site R), Bahía Túnel (Lago Viedma), Brazo Maipú (Lago San Martín/O’Higgins) and Los Antiguos (Lago Buenos Aires/General Carrera). These data sets are also summarized in Tab. 1. In addition we use meteorological data at El Calafate provided by the Servicio Meteorológico Nacional.

Continuous lake-level time series were derived from the pressure tide gauge records. The observed pressure values were corrected for the air pressure recorded at El Calafate and converted to the metric height of the water column above the pressure sensor. At this step, water density values were applied that were derived from the water temperature recorded simultaneously with the pressure. A possible drift of the tide gauge clock was corrected linearly by an independent cross-check at the beginning and end of each record. GPS observations on a floating buoy at the tide gauge location during deployment and recovery of the tide gauges (Del Cogliano et al., 2007), as well as synchronous lake-level observations at neighbouring sites were used to adjust the vertical offset of the sensor position between the individual tide gauge deployments at site $\mathrm{C}$ and to verify the stable position of the pressure sensors throughout their operation. Details on the tide gauge data processing are given in Richter et al., 2005. The lakelevel time series for sites $\mathrm{C}$ and $\mathrm{W}$ are shown in Fig. 2. The pressure tide gauges employed here have been shown by Richter et al. (2010) under similar conditions (Lago Fagnano) to achieve measurement accuracies of 2 to 3 $\mathrm{mm}$ for a single relative lake-level reading. Documentation of the BDHI water-level data, however, is sparse, thus an evaluation of the reliability and accuracy of this data set is a secondary objective of the present work.
The obtained time series of relative lake-level variations are considered in the following as realisations of stochastic processes (Richter et al., 2010). Time series analysis tools are applied to identify the driving forces and mechanisms behind the observed variations. In particular, stacking and the Fast Fourier Transformation of the time series into the frequency domain are used to extract periodical variation contributions. The small but distinct signals of lake tides are derived by a harmonic tidal analysis using the TASK2000 software package (Bell et al., 1998). This yields the amplitudes and phase lags (with respect to equilibrium high tide at the $0^{\circ}$ meridian) for the four major tidal constituents M2, S2, O1 and K1.

\section{Lake tide modelling}

The contribution of astronomic tides to observable lake-level variations have been theoretically predicted by lake-tide models for the great Patagonian lakes (Lagos Buenos Aires/General Carrera, San Martín/O’Higgins, Viedma, Argentino and Fagnano; Marderwald, 2014). For each lake, on a regular grid with a resolution of $100 \mathrm{~m} \mathrm{x}$ $100 \mathrm{~m}$ the amplitudes and phases of seven diurnal and semi-diurnal constituents (Q1, O1, P1, K1, N2, M2 and S2) were computed. The lake-tide modelling includes the contributions of both the solid earth's body tides and the ocean tidal loading (Richter et al., 2009). Both contributions involve a deformation of the surface of the solid earth (i.e., lake bed) and of the equipotential surfaces of the gravity field (to which the water surface adjusts). For the load tide computation the global ocean tide model EOT11a (Savcenko and Bosch, 2008) and the GutenbergBullen A earth model (Farrell, 1972) was applied. The conservation of water volume is taken into account.

According to the modelling results, lake tides generate

Tab. 1. Lake-level records in Lago Argentino (sites C-R) and other great Patagonian lakes included in the analysis. For each tide gauge site, the geographical location and coordinates, the total amount of lake-level readings, the dates (dd/mm/yyyy) of the start and end and the nominal sampling rate for each record are given.

\begin{tabular}{|c|c|c|c|c|c|c|c|}
\hline Site & Location & Lat. S & Lon. W & Readings & Start & End & Rate \\
\hline $\mathrm{C}$ & Punta Bandera & $50^{\circ} 18.0^{\prime}$ & $72^{\circ} 47.8^{\prime}$ & 127510 & $\begin{array}{l}12 / 12 / 2011 \\
09 / 03 / 2012 \\
24 / 02 / 2013\end{array}$ & $\begin{array}{l}08 / 03 / 2012 \\
24 / 02 / 2013 \\
17 / 08 / 2014\end{array}$ & $\begin{array}{c}5 \mathrm{~min} \\
10 \mathrm{~min} \\
15 \mathrm{~min}\end{array}$ \\
\hline W & Bahía Toro & $50^{\circ} 17.3^{\prime}$ & $73^{\circ} 15.9^{\prime}$ & 50551 & $08 / 03 / 2012$ & $22 / 02 / 2013$ & $10 \mathrm{~min}$ \\
\hline $\mathrm{E}^{*}$ & El Calafate & $50^{\circ} 19.2^{\prime}$ & $72^{\circ} 15.7^{\prime}$ & 8160 & $08 / 01 / 1992$ & $30 / 10 / 2014$ & $24 \mathrm{~h}$ \\
\hline $\mathrm{R}^{*}$ & Brazo Rico & $50^{\circ} 29.4^{\prime}$ & $72^{\circ} 57.0^{\prime}$ & 8097 & $15 / 11 / 1991$ & $30 / 10 / 2014$ & $24 \mathrm{~h}$ \\
\hline Lago Viedma* & Bahía Túnel & $49^{\circ} 23.7^{\prime}$ & $72^{\circ} 52.2^{\prime}$ & 14546 & $\begin{array}{l}01 / 03 / 2010 \\
24 / 09 / 2010 \\
15 / 11 / 2010 \\
23 / 09 / 2011\end{array}$ & $\begin{array}{l}23 / 09 / 2010 \\
15 / 11 / 2010 \\
22 / 09 / 2011 \\
30 / 09 / 2014\end{array}$ & $\begin{array}{l}24 \mathrm{~h} \\
4 \mathrm{~h} \\
1 \mathrm{~h} \\
4 \mathrm{~h}\end{array}$ \\
\hline $\begin{array}{l}\text { Lago Buenos Aires/ } \\
\text { General Carrera* }\end{array}$ & Los Antiguos & $46^{\circ} 32.3^{\prime}$ & $71^{\circ} 36.6^{\prime}$ & 6522 & $18 / 09 / 2008$ & $29 / 09 / 2014$ & $8 \mathrm{~h}$ \\
\hline Lago San Martín/O’Higgins* & Brazo Chacabuco & $49^{\circ} 07.4^{\prime}$ & $72^{\circ} 29.1^{\prime}$ & 1678 & $01 / 03 / 2010$ & $29 / 09 / 2014$ & $24 \mathrm{~h}$ \\
\hline
\end{tabular}

*Data sets retrieved from $\mathrm{BDHI}(2015)$. 
anti-clockwise gyres about an amphidrome close to the geometric centre of the lake area. Maximum amplitudes are located at the lake's most distant points from this amphidrome. The narrow shape of Lago Fagnano and the glacier valleys composing Lago San Martín/O’Higgins makes the tidal circulation appear there as a seesaw-like tilt of the water surface (Richter et al., 2009). The patterns of amplitudes and phases are similar for all the constituents. The predicted maximum amplitudes for the five lakes and the four major tidal constituents are given in Tab. 2. The definition of the lake grids involved the extraction of high-resolution shoreline polygons from satellite imagery. Selected morphometric parameters inferred from these shoreline polygons are also added in Tab. 2.

\section{RESULTS}

\section{Seasonal lake-volume signal}

Fig. 2a reveals that long-term lake-level changes occur uniformly at sites $\mathrm{C}$ and $\mathrm{W}$. This leads to the conclusion, confirmed by the synchronous lake-level signal at site $\mathrm{E}$, that this signal is common to the entire lake surface and thus reflects changes in the water volume contained in the lake. The lake-volume variation is dominated by an annual period. Stacking of the lake-level variations observed at site $\mathrm{C}$ over a period of one year in Fig. 3a reveals a mean seasonal cycle with an amplitude of about $1.2 \mathrm{~m}$. The lake level peaks in March, at the end of the austral summer, and reaches a minimum in October. The maxi-

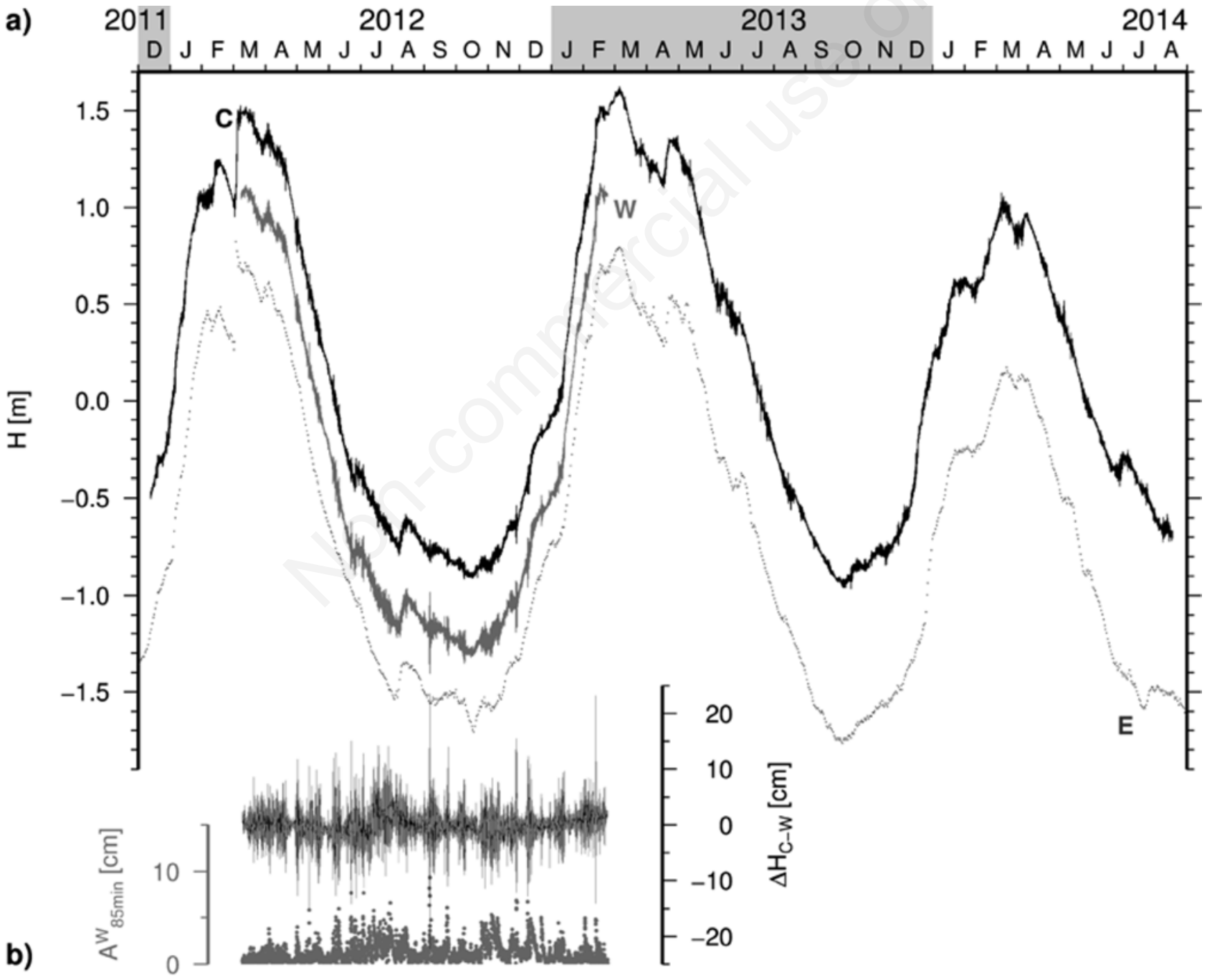

Fig. 2. a) Lake-level time series derived from pressure tide gauge records at sites C (black) and W (light grey); grey dotted line, lakelevel data for site E from BDHI (2015). b) For the period of simultaneous tide gauge operation, the time series of differential lake-level changes between sites $\mathrm{C}$ minus $\mathrm{W}$ are shown in black; grey dots, time series of the surface seiches amplitude at site $\mathrm{W}$ for the fundamental seiches mode with a period of $85 \mathrm{~min}$. 
mum is more confined in time than the minimum. The lake-level cycle lags the seasonal air temperature signal by two (maximum) to three (minimum) months.

In Fig. $3 b$ the seasonal lake-level cycle at site $C$ is compared to that derived for site $\mathrm{E}$ for the 5-year periods 1992-1996 (dashed) and 2010-2014 (solid). The more recent mean annual lake-level signal at site $\mathrm{E}$ matches closely that of site $\mathrm{C}$. The slightly less pronounced lakelevel minimum at site $\mathrm{E}$, the only apparent difference, may be attributed to the difference in observation period at both sites ( 5 years at site E vs 2.5 years at site C). The mean annual cycle corresponding to the earlier period 1992-1996, in turn, reveals a smaller amplitude compared to that of the recent signal at the same site and, more importantly, a time shift in the lake-level minimum of approximately one month.

We interpret this as an indication and consequence of climatically induced regional changes of environmental parameters. The change observed in the seasonal lake-volume signal might be interpreted in the way, that both snow accumulation and the onset of melting in the mountains surrounding Lago Argentino are occurring today roughly one month later than 18 years ago, manifesting a progressive lag of the seasonal cycles of meteorological (and thus also hydrological) parameters. It might also be indicative of increased glacier melting in recent years due to warming climate, thus increasing the annual lake-level amplitude and delaying the drop after the peak related to the yearly depletion of the seasonal snow cover.

Alternatively, this change of the seasonal signal may be the consequence of a secular trend in the lake-level data. In fact, the site $\mathrm{E}$ record yields a mean lake-level rate of approximately $+1.5 \mathrm{~cm} / \mathrm{a}$, corresponding to a total lake-level rise of $34 \mathrm{~cm}$ over the observation period of almost 23 years. This progressive increase steepens the lake-level rise, as observed during the first few months of the year (Fig. 3b), and decelerates the lake-level drop resulting altogether in a delay of the lake-volume minimum. There remains, however, the question of the origin of the observed lake-level rise. A recent model of crustal deformation induced by glacial- isostatic adjustment around the Southern Patagonian Icefield (Lange et al., 2014) suggests for the Lago Argentino area a progressive tilt of the solid earth surface with faster uplift at tide gauge site E compared to the lake's outlet into Río Santa Cruz. Assuming an unchanged lake outlet throughout the observation period, this relative crustal uplift would result in an approximately $2 \mathrm{~mm} / \mathrm{a}$ lake-level decrease at tide gauge $\mathrm{E}$, contrary to what is observed. Thus, a quasi-secular lakevolume increase of $2.3 \cdot 10^{7} \mathrm{~m}^{3} \mathrm{a}^{-1}$, corresponding to a lake-level rise of $1.7 \mathrm{~cm} / \mathrm{a}$, would be required to explain the observed trend. Since enhanced influx into the lake is counterbalanced by an increase in run-off, a persistent acceleration in the influx would be required to sustain a lake-level rise over two decades. This, in turn, would be a testimony of an indeed dramatic recent mass loss of the glaciers at the eastern flank of the Southern Patagonian Icefield. However, the sparse documentation of the lakelevel data published for site E, lacking, for example, information on regular control levelling, may not guarantee a stable vertical position of the tide gauge sensor throughout the observation period. The apparent lake-level rise at site $E$ could therefore also be an artefact by subsidence of the tide gauge. The large annual amplitude and the recurrence of sudden jumps due to ruptures of Perito Moreno glacier make it particularly difficult to find evidence for a tide gauge instability in the lake-level record.

The mean seasonal lake-level signal at site $\mathrm{C}$ is shown in Fig. $3 \mathrm{c}$ together with that derived for other Patagonian lakes. Clearly, the amplitude of the lake-level cycle in

Tab. 2. Morphometric parameters for the great Patagonian lakes. Below, the maximum amplitudes of the principal tidal constituents M2, S2, K1, O1 predicted by lake tide models for each lake are given. For the M2 constituent, also the phase lags (relative to the $0^{\circ}$ meridian) and the contributions of body tide (Body) and load tide (Load) are included.

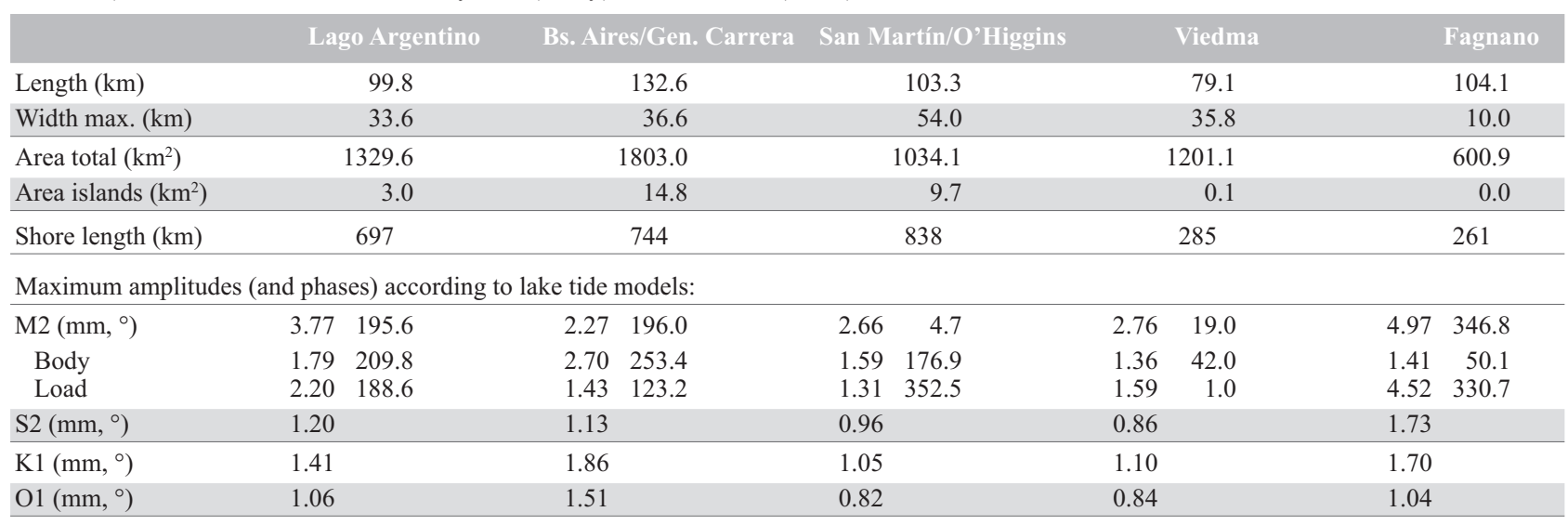


Lago Argentino exceeds by far that of Lagos Fagnano, Buenos Aires/General Carrera and Viedma. Only Lago San Martin/O'Higgins shows a comparable, even slightly larger, annual lake-level range as Lago Argentino. It should be noted, however, that the lake-level data of Lago San Martin/O'Higgins represent the most sparsely and unevenly sampled among all the records used here, and that therefore the mean annual signal determined for this lake could be less accurate (suggested also by its more irregular shape). The differences between the annual lake-level amplitudes of the Patagonian lakes result from a combination of unequal intensity of glacial influence (e.g., Lago Argentino $v s$ Lago Fagnano) and differing ratios of catchment $v s$ lake area (e.g., Lago Argentino vs Lago Viedma).

\section{Response to short-term forcing: seiches}

In Fig. 2a sporadic events of differential lake-level variations between sites $\mathrm{C}$ and $\mathrm{W}$ become evident. A zoom into the lake-level time series during the most pronounced of these events in September 2012 is shown in Fig. 4a. It reveals that the lake-level differences between sites $\mathrm{C}$ and W (Fig. 2b) are due to periodical oscillations with much larger amplitude at site $\mathrm{W}$ than at $\mathrm{C}$. These oscillations are composed of several periods the predominant of which is about $1.5 \mathrm{~h}$. Between late 4 and early 5 of September 2012 the amplitude increases steadily until reaching 20 $\mathrm{cm}$ around 5:00 UTC. The oscillation amplitude then diminishes rapidly. At site $\mathrm{W}$ the oscillation continues afterwards with slowly fading amplitude. The onset and build-up of the lake-level oscillations are synchronous with strong westerly winds (Fig. 4a).

These periodic variations are the manifestation of surface seiches and represent resonant oscillations of the water body (Forel, 1895). Their excitation depends on external forcing, such as strong winds, thus the timing of their occurrence and their magnitude are governed nonlinearly by the temporal evolution of these forces. The frequency, or period, of these oscillations, however, are determined by the geometry of the water body and are therefore invariable. Surface seiches are often composed of oscillations on several frequencies each of which represents a distinct seiches mode (Richter et al., 2010). For the simple model of a one- dimensional channel of uniform cross section, these modes represent standing waves with a characteristic number of nodes, and Merian's formula relates their oscillation period with the length and depth of the channel (Mortimer, 1974). In the case of Lago Argentino, however, the lack of bathymetric information impedes a straightforward prediction of the surface seiches frequencies based on Merian's formula.

Figs. $4 \mathrm{~b}$ and $4 \mathrm{c}$ show the amplitude spectra of the lake-level variations recorded at sites $\mathrm{C}$ and $\mathrm{W}$, respectively, throughout the common observation period (approximately one year). The surface seiches modes appear

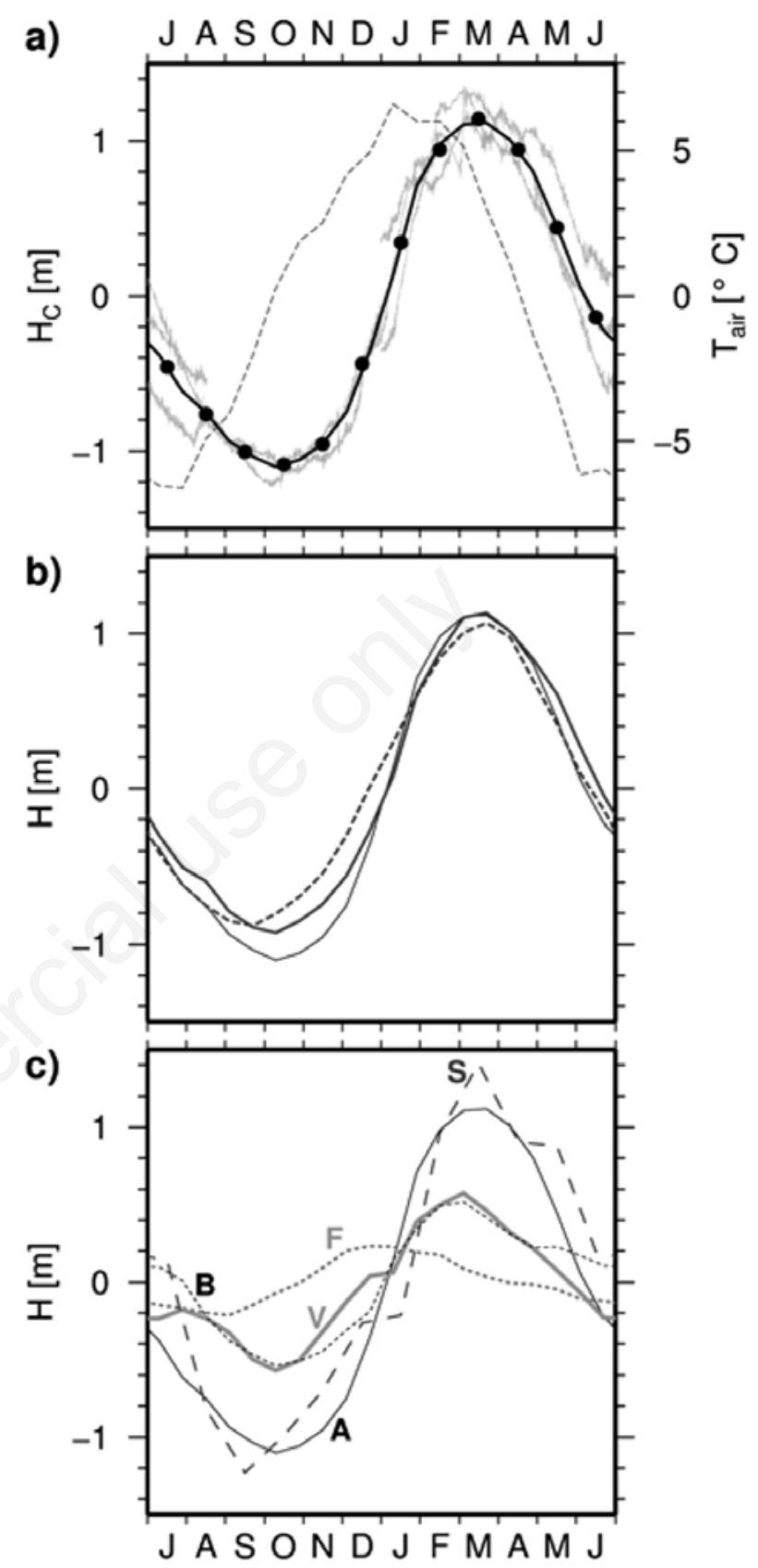

Fig. 3. Stacked annual lake-level signal (July 1 June 30). a) Original (light grey) and stacked mean annual lake-level signal, $\mathrm{H}_{\mathrm{C}}$, observed at site $\mathrm{C}$; dashed line, stacked mean annual air temperature observed at El Calafate (2010-2014), $\mathrm{T}_{\text {air }}$; letters indicate the months. b) Comparison of the stacked mean annual lakelevel signal at site $\mathrm{C}$ (thin black line) with the corresponding lake-level signal derived for site E for the period 1992-1996 (dashed grey line) and 2010-2014 (solid grey line). c) Comparison of the stacked mean annual lake-level signal derived at site C for Lago Argentino (A, solid black) with the corresponding signals for Lagos San Martín/O'Higgins (S, long dashed; BDHI, 2015), Buenos Aires/General Carrera (B, black dotted; BDHI, 2015), Viedma (V, thick grey; BDHI, 2015) and Fagnano (F, grey dotted; Richter et al., 2010). 
in the spectra as sharp peaks centred on their characteristic frequencies. Site $\mathrm{C}$ exhibits only one prominent seiches mode with a frequency of 17 cycles per day corresponding to a period of 85 minutes. The same frequency represents also the dominant seiches mode at site $\mathrm{W}$. This is the prevailing mode observed in the lake-level oscillation depicted in Fig. 4a. The perfect agreement in frequency between the two spectra proves that both sites participate in one and the same surface seiches mode. The about three times larger amplitude of this mode at site $\mathrm{W}$ compared to site $\mathrm{C}$ indicates that the node of this mode is much closer to the site $\mathrm{C}$ than $\mathrm{W}$. The approximate agreement in the phases (not shown in Fig. 4) of this peak in both spectra suggests furthermore that both tide gauge sites are located to the same side of the node. This supports the assumption that this seiches mode represents the fundamental, uninodal standing wave extending between the lake's eastern shore up to the head of Brazo Mayo in the west (Fig. 1). Applying Merian's formula to this extension (88 $\mathrm{km})$ and period $(85 \mathrm{~min}$ ) yields a hydrodynamically effective water depth of $120 \mathrm{~m}$. This value is reasonably close to the little substantiated statement of a mean lake depth of $150 \mathrm{~m}$ (Quirós et al., 1988). Alternatively, the identified period could correspond to the uninodal mode of an oscillation system extending over $96 \mathrm{~km}$ from the head of Brazo Upsala (NW tip of the lake) through Brazo Norte and Brazo de los Tempanos to the head of Brazo Mayo. In this case the effective mean water depth would amount to $142 \mathrm{~m}$. A conclusive decision between the two cases is not possible on the basis of the available data.

The amplitude spectrum of the lake-level variations at site W (Fig. 4c) reveals, in addition to the fundamental mode, four smaller peaks resembling the spectral imprint of surface seiches. The corresponding oscillation periods amount to 28, 36.5, 58, and $107 \mathrm{~min}$, respectively. The fact that these peaks are absent at tide gauge $\mathrm{C}$ implies that this site either remains outside of the oscillation system or that it coincides with a node of the standing wave. In an attempt to explain the observed oscillation frequencies we apply again Merian's formula as well as the effective water depth derived for the fundamental surface seiches mode between eastern shore and Brazo Mayo $(120 \mathrm{~m})$. This model predicts an oscillation period of 36.5 min for the uninodal seiches mode for the $38 \mathrm{~km}$ long water body comprising Brazo Mayo and the southern branch of Brazo de los Tempanos up to Glacier Perito Moreno (Fig. 1b). The perfect agreement of this modelled period with one of the peaks found in the spectra gives confidence not only in the correct identification of this seiches mode, but also in the adequacy of the adopted effective water depth and thus the consistency of the explanation of the fundamental seiches mode. For the third mode (three nodes) of the lake-wide oscillation system (eastern lake shore up to Brazo Mayo) Merian's for- mula yields a theoretical period of 28.5 minutes, very close to the observed peak at $28 \mathrm{~min}$. One of the nodes must be located close to site $\mathrm{C}$, since this seiches mode is not observed at that tide gauge. Since the main basin of Lago Argentino is expected to be considerably shallower than the narrow glacier valleys in the west, it is very likely that the nodes of this oscillation system are not distributed symmetrically, but systematically shifted towards east. It appears therefore plausible that the westernmost of the three nodes of this seiches mode would coincide with site C. The period of $58 \mathrm{~min}$, corresponding to yet another observed spectral peak, equals exactly two thirds of the fundamental seiches mode. This fact motivates the speculation that this seiches mode represents a rotational circulation over the three sub-basins Brazo Mayo/Brazo de los Tempanos (W), Brazo Norte/Brazo Upsala (NW) and the lake's main basin (E). The length of these sub-

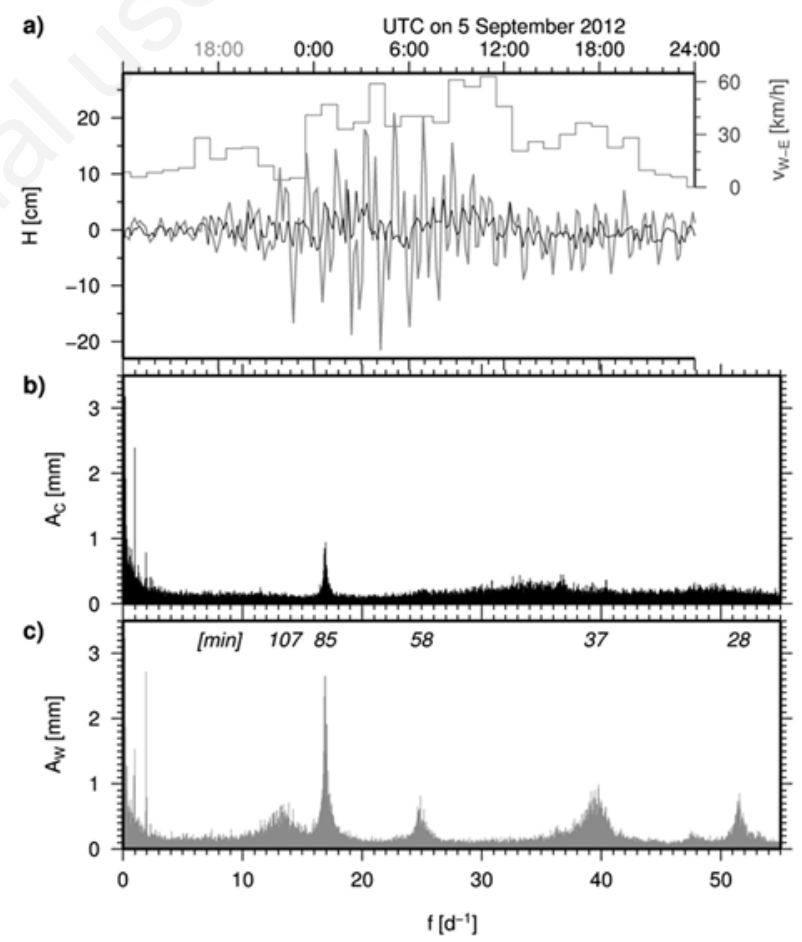

Fig. 4. Surface seiches observed in Lago Argentino. a) Simultaneous lake-level time series at sites C (black) and W (grey) from late 4 to 5 September 2012 showing the onset and evolution of a seiches series; jagged grey line, east-west wind velocity component $\mathrm{v}_{\mathrm{W}-\mathrm{E}}$ observed at El Calafate. b) Amplitude spectrum of the lake-level variations observed at site $\mathrm{C}$ throughout the common observation period at sites $\mathrm{C}$ and $\mathrm{W}$; the prominent peak at frequency $\mathrm{f}=17 \mathrm{~d}^{-1}$ (cycles per day) represents the fundamental surface seiches mode with a period of $85 \mathrm{~min}$; large amplitudes at low frequencies are truncated. c) Amplitude spectrum for site $\mathrm{W}$ analogous to $\mathrm{b}$ ); for the frequencies with significant seiches amplitudes the corresponding period (min) is included. 
basins is indeed comparable $(41,53$, and $58 \mathrm{~km}$, respectively) which implies the location of an amphidrome at their junction just off tide gauge site $\mathrm{C}$. The remaining peak, corresponding to the longest period of $107 \mathrm{~min}$, appears in the spectrum flatter and stretched over a broader frequency range than the other peaks. This appearance is typical for alias frequencies of short-period seiches modes not properly resolved by the observation rate (Richter et al., 2010). This peak could therefore represent an alias signature of a seiches mode in the short oscillation system between Bahía Toro (i.e., site W) and the head of Brazo Mayo (SW). For the length of this system $(7 \mathrm{~km})$ and the depth representative for the entire lake $(120 \mathrm{~km})$ Merian's formula yields an oscillation period of $7 \mathrm{~min}$. Such a short period is indeed not resolved by the lake- level observations at site $\mathrm{W}$ with a 10 min interval and therefore must produce an alias signature in the spectrum. However, an unambiguous relation of the peak frequency to this seiches mode would require knowledge of the water depth representative for this small water body. The surface seiches modes identified in the amplitude spectra are summarized in Tab. 3.

In Fig. 2b, bottom, the time series of the amplitude of the fundamental seiches mode observed at site $\mathrm{W}$ is included. It demonstrates the coincidence of large seiches amplitudes with practically all occurrences of significant differential lake-level variations between sites $\mathrm{C}$ and $\mathrm{W}$. This indicates that relative lake-level changes between both sites result to a very large extent from surface seiches. Furthermore, almost all events of differential lakelevel change and increased surface seiches synchronize with the occurrence of increased wind speeds at El Calafate (not shown in Fig. 2). This allows the conclusion that wind is the primary force exciting surface seiches in Lago Argentino.

\section{Lake tides}

Our lake tide model for Lago Argentino predicts generally larger tidal amplitudes at site $\mathrm{W}$ than at $\mathrm{C}$, consis- tent with the formation of amphidromes close to the lake centre. This is confirmed by the amplitude spectra of the lake-level variations observed at both sites (Figs. 4b, c). While the spectrum of site $\mathrm{W}$ shows an amplitude of the semi-diurnal lunar tidal constituent M2 $\left(1.93 \mathrm{~d}^{-1}\right)$ close to $3 \mathrm{~mm}$, the corresponding amplitude at site $\mathrm{C}$ remains below $1 \mathrm{~mm}$.

According to our modelling, the M2 constituent is expected to produce the largest contribution to the tidal lakelevel variations in all Patagonian lakes (Tab. 2). Moreover, the M2 period is sufficiently distinct from solar (daily) periods to allow a relatively clear separation of the astronomic tides from contributions related to environmental parameters with a daily cycle. For this reason, we consider in this section the M2 constituent only.

The harmonic tidal analysis of the lake-level time series from sites $\mathrm{W}$ and $\mathrm{C}$ yields the amplitudes and phases for the four main tidal constituents given in Tab. 4. The comparison of the M2 tidal constants extracted from the lake-level observations with the prediction of our lake tide model is depicted in the phasor plots in Figs. 5 a,b detailing individually the modelled contributions of the body tide (light grey) and the load tide (dark grey). Site W shows a difference in amplitude of $0.02 \mathrm{~mm}$ and a roughly $23^{\circ}$ phase lag of the model relative to the observed signal. This degree of agreement proves our modelling approach in general valid. While the amplitude difference is fully explained in its magnitude by expected observation and model uncertainties, the $23^{\circ}$ phase difference seems somewhat large to be explained entirely by the usual inconsistencies between model and observational determination. In fact, both the order of magnitude of the differences and the internal geometry between the vectors representing the body tide, load tide and observed lake tide signals are also observed at site $\mathrm{C}$ despite the much smaller signal magnitude there (Fig. 5b). The result of a harmonic tidal analysis of the hourly lake-level data at Bahía Túnel in Lago Viedma is added in Fig. 5d (black). We regard the observational vector as less reliable than those presented

Tab. 3. Surface seiches modes observed in Lago Argentino (site W). The frequency $\mathrm{f}_{\mathrm{obs}}$ and corresponding period $\mathrm{T}_{\mathrm{obs}}$ are given for significant peaks in the amplitude spectrum (Fig. 4c). The quantities water depth D, basin length $\mathrm{L}$, the number of nodes $\mathrm{n}$ and the resulting theoretical period $\mathrm{T}_{\bmod }$ involved in a model applying Merian's formula are added. Numbers underlined indicate the unknown quantity for which Merian's formula was solved. The last column indicates the geographical extent of the oscillation system (Fig. 1b).

\begin{tabular}{|c|c|c|c|c|c|c|}
\hline $\mathrm{T}_{\mathrm{obs}}(\mathrm{min})$ & $f_{o b s}\left(d^{-1}\right)$ & $\mathrm{T}_{\bmod }(\min )$ & $\mathrm{D}(\mathrm{m})$ & $\mathrm{L}(\mathrm{km})$ & n & Oscillation system \\
\hline 85.4 & 16.9 & & 120.8 & 88.2 & 1 & Main basin, BT, BM \\
\hline 57.9 & 24.9 & $\underline{56.9}$ & 120.8 & $53-41-58$ & $\mathrm{C}$ & Main basin - BT, BM - BN, BU \\
\hline 36.5 & 39.5 & $\underline{36.5}$ & 120.8 & 37.7 & 1 & BT, BM \\
\hline 28.0 & 51.4 & $\underline{28.5}$ & 120.8 & 88.2 & 3 & Main basin, BT, BM \\
\hline \multirow[t]{2}{*}{107.3} & 13.4 & $\underline{7.2}$ & 120.8 & 7.4 & 1 & BM western part \\
\hline & & $\underline{5,11}$ & \multicolumn{4}{|c|}{ Signal periods producing an alias frequency of $13.4 \mathrm{~d}^{-1}$ when sampled at 10 min rate } \\
\hline
\end{tabular}

$n=C$ means a rotational circulation over three sub-basins. 
for sites $\mathrm{C}$ and $\mathrm{W}$ in Lago Argentino due to the lack of timing and quality control of the lake-level readings and incomplete metadata (e.g., the data are assumed to be given with respect to the official Argentine time zone, although this is nowhere documented explicitly). Nevertheless, the geometrical relation between the body tide, load tide and observed tide vectors at this site is strikingly similar to that found at both tide gauges in Lago Argentino. This leads to the conclusion that the phase lags encountered between lake tide model and observed M2 signals are of a systematic origin common to the region beyond a specific site or lake.

\section{Singular events}

The tide-gauge records from Lago Argentino allow us to study also processes not as commonly manifested in lake-level changes as surface seiches, lake tides or the annual water-volume cycle. The first of two examples is the rapid water displacement caused by the bursting of the snout of Perito Moreno glacier (Pasquini and Depetris, 2011). Over extended periods of time this glacier dams the outlet of Brazo Rico and Brazo Sur against the rest of Lago Argentino causing a rise in water level in the isolated south-eastern branch. In more or less regular intervals, when the pressure of the water column at the foot of the glacier reaches a certain threshold, the icy dam breaks in an instantaneous event giving way to the outburst of the water piled up in Brazo Rico/Sur into the proper Lago Argentino. Our lake-level record at site $\mathrm{C}$ includes one of these spectacular events that occurred on March 2, 2012. This outburst produced a sudden lake-level rise at site $\mathrm{C}$ of approximately $45 \mathrm{~cm}$, clearly evident in Fig. 2a. A zoom into the lake-level time series in Fig. 6a shows that the lake-level rise is preceded by relatively large oscillations, probably surface seiches. The precipitation record at El Calafate rules out a major contribution of rainfall to

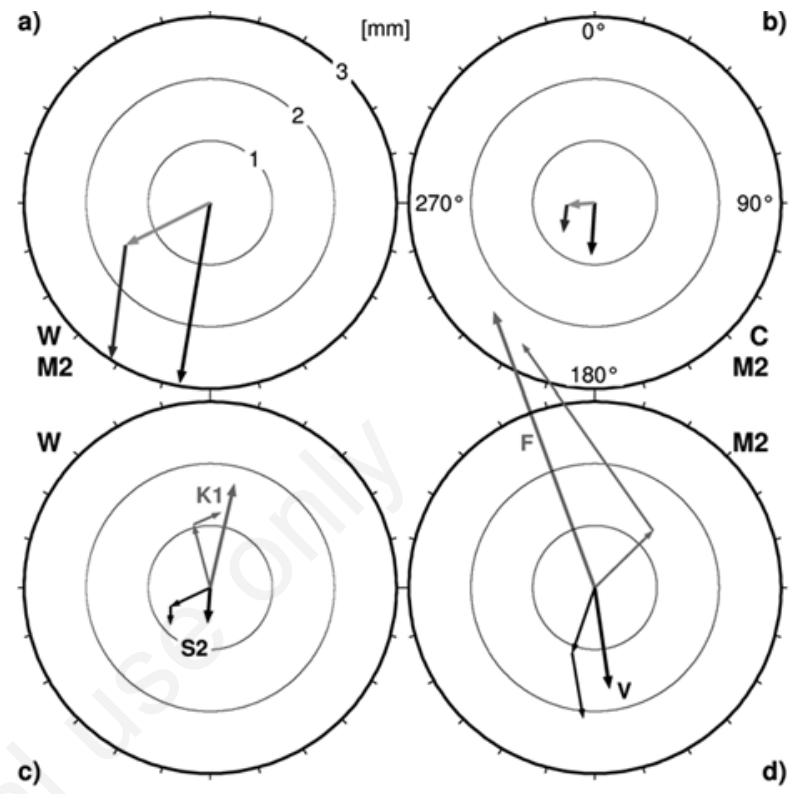

Fig. 5. Phasor plots of the observed vs modelled lake tide signals. a) M2 lake tide signal extracted from the lake-level observations at site $\mathrm{W}$ (black); light grey and dark grey vectors depict the modelled contributions of body tide and load tide, respectively, to the theoretical lake tide signal at this site; for a perfect agreement between observations and model the vectors would meet. b) Same as a) for site C. c) For the K1 (grey) and S2 (black) tidal constituents the lake tide signals extracted from the lake-level observations at site W (thick) and the model contributions of body tide and load tide (thin) are shown. d) For Lagos Fagnano (F, grey, site C in Richter et al., 2009) and Viedma (V, black, Bahía Túnel; BDHI, 2015) the observed (thick) M2 lake tide signal and the modelled contributions of body tide and load tide (thin) are shown.

Tab. 4. Lake tide parameters at sites $\mathrm{W}$ and $\mathrm{C}$ in Lago Argentino. For the principal tidal constituents M2, S2, K1, O1 the amplitudes $\mathrm{A}$ and phase lags $\mathrm{G}$ (relative to the $0^{\circ}$ meridian) derived from the observed lake-level time series are given. Note that only the M2 lake tide signal is regarded as statistically significant. The theoretical parameters according to the lake tide model for both sites, together with the modelled contributions of body tide and load tide are included.

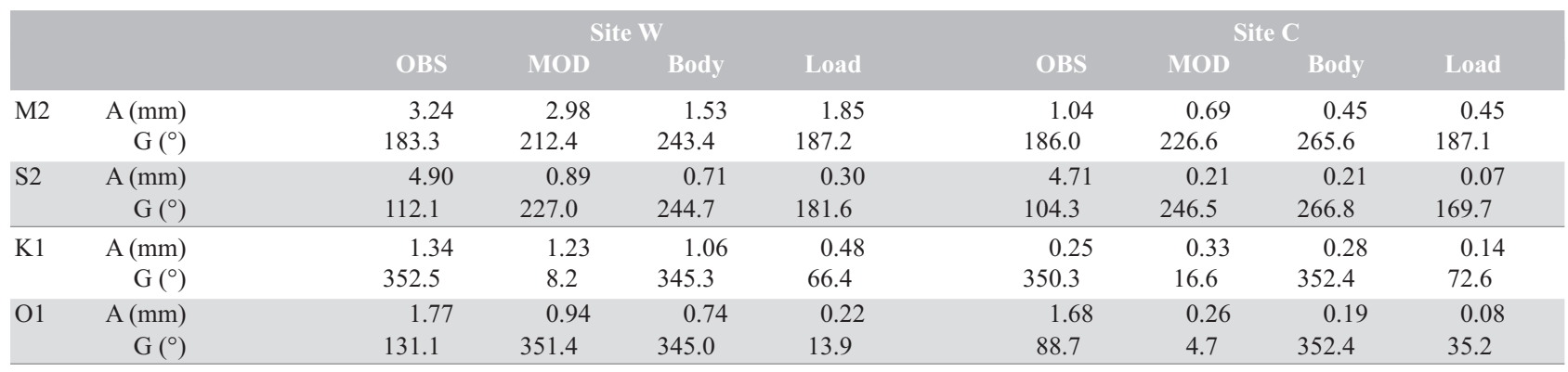

OBS, observed lake-level time series; $M O D$, lake tide model. 
this lake-level jump. According to the record from site R, the water level in Brazo Rico dropped between March 1 and 11,2012 by more than $5.5 \mathrm{~m}$. The ratio between lakelevel rise at site $\mathrm{C}$ and drop in Brazo Rico corresponds to the ratio in surface area of both water bodies of 1:11 as expected from volume conservation. The lake-level rise at site $\mathrm{C}$ completes within two days (Fig. 6a). We conclude that the redistribution of the water from Brazo

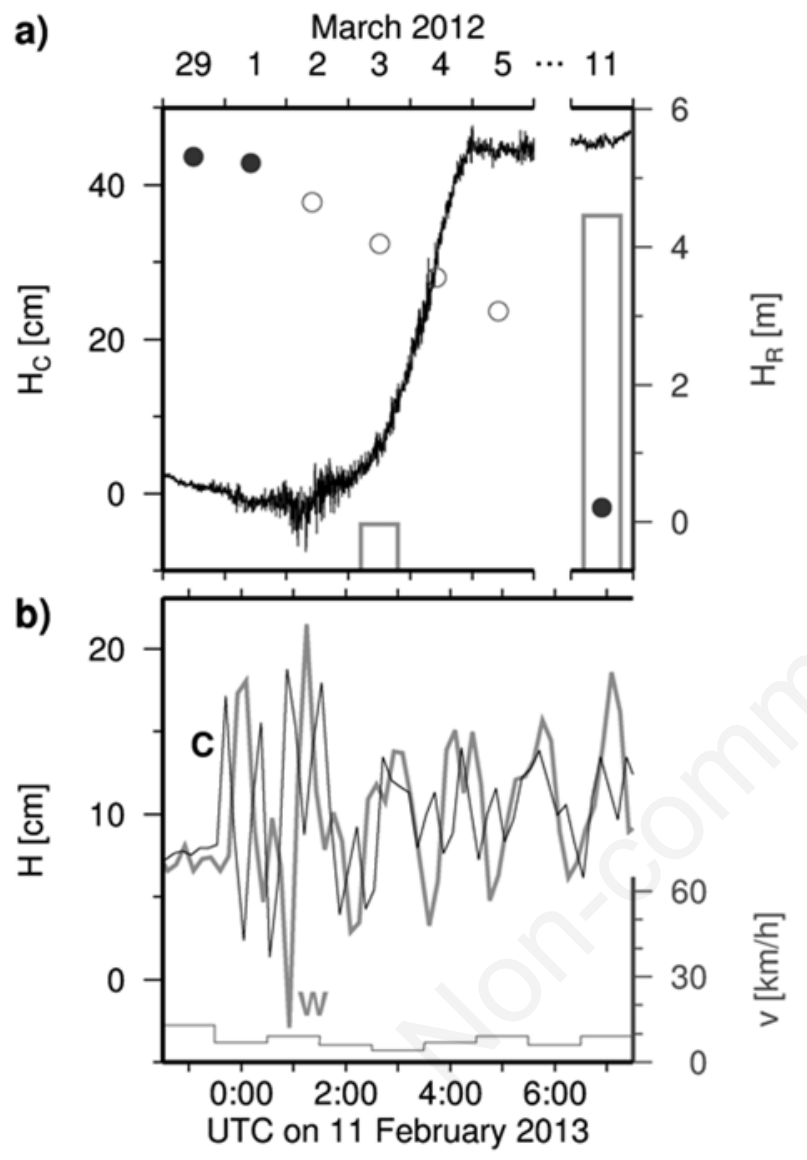

Fig. 6. Lake-level time series during singular events. a) Lakelevel variation observed at site $\mathrm{C}, \mathrm{H}_{\mathrm{C}}$ (black, left axis annotation) during and after the ice dam burst of Perito Moreno glacier on March 2, 2012; grey dots, simultaneous lake-level readings at site $\mathrm{R}$ in Brazo Rico $\mathrm{H}_{\mathrm{R}}$ (axis annotation to the right; BDHI, 2015); open circles, implausible lake-level data likely resulting from linear interpolation (see text); the relative axis scale for $\mathrm{H}_{\mathrm{C}}$ and $H_{R}$ corresponds to the ratio of surface area between the proper Lago Argentino and Brazo Rico/Sur of 1:11; grey bars indicate rainfall as observed at El Calafate meteorological station (larger bar on March 11 corresponds to $5 \mathrm{~mm}$ ). b) Lakelevel time series observed at sites C (black) and W (grey) from late 10 to 11 February 2013 showing the passage of a flood wave and onset of a surface seiches series following a landslide in Brazo Upsala; the jagged grey line at the bottom indicates the wind speed v recorded at El Calafate meteorological station.
Rico/Sur is accomplished in this time span. This implies a mean water flux of $3600 \mathrm{~m}^{3} \mathrm{~s}^{-1}$ across the passage at Perito Moreno glacier. For comparison, the maximum flux observed in upper Río Santa Cruz amounts to just $2250 \mathrm{~m}^{3} \mathrm{~s}^{-1}$ (BDHI, 2015). Another conclusion is that the linearly decreasing daily water-level values between March 2 and 10, 2012 published in the record of site R (open circles in Fig. 6a) most likely result from interpolation rather than observation.

The second example of rare events affecting Lago Argentino's water level is illustrated in Fig. 6b. It shows the onset of a surface seiches series, first at site $\mathrm{C}$ before propagating to site $\mathrm{W}$, around midnight between February 10 and 11,2013 . In fact, this event represents the second largest differential lake-level change between sites $\mathrm{C}$ and W depicted in Fig. 2b. Strikingly, this seiches series, exceeding $20 \mathrm{~cm}$ in range at site $\mathrm{W}$, is not accompanied by strong winds: the El Calafate meteorological station reports wind speeds below $10 \mathrm{~km} / \mathrm{h}$ throughout this period. Moreover, the oscillations at both sites are initially in antiphase. Only after about 2:00 UTC they align in phase as usual for the fundamental seiches mode. The cause of these lake-level oscillations consists in a large landslide in Brazo Upsala close to the front of Upsala glacier. Since it occurred at night, in a remote glacier valley accessible only navigating, there exists probably no direct observation of this event. The following day, however, the denuded mountain flank was discovered by tourist boats. Along the lake shore of this channel, large ice chunks and tree trunks were found several meters above the lake level, testifying the impact of what can be imagined as a microanalogy of a tsunami in the channel. The phase lead of the oscillation onset at site $\mathrm{C}$ relative to site $\mathrm{W}$ is consistent with the propagation of the flood wave from Brazo Upsala down Brazo Norte to site $\mathrm{C}$ and from there up Brazo de los Tempanos and Brazo Mayo. The 13 min time lag it took this wave to cover the $35 \mathrm{~km}$ between both tide gauges implies a mean propagation speed of $160 \mathrm{~km} / \mathrm{h}$. Assuming this wave speed to be representative also for the upper course of the flood wave leads to the estimate that the landslide occurred at 23:12:30 UTC on February 10,2013 . This information is important to disclose the cause, and probability of recurrence, of the catastrophic event which may represent a potential hazard for the local tourist activities, for example by examination of earthquake catalogues for nearby seismic events.

\section{Daily lake-level cycle}

Fig. 7a shows the mean daily lake-level cycle at site $\mathrm{C}$ as derived from stacking of the observed lake-level time series over a period of $24 \mathrm{~h}$. It is characterized by an amplitude of almost $2.5 \mathrm{~mm}$ with the maximum occurring between 22:00 and 23:00 UTC and a minimum between 8:00 and 9:00 UTC. In Fig. 7b this daily lake-level cycle is com- 
pared to that derived for site W. Despite its much shorter duration, the record from site $\mathrm{W}$ yields a daily lake-level peak practically synchronous in time and comparable in amplitude with that observed at site $\mathrm{C}$. This leads to the conclusion that an essential part of the lake-level variation with daily period occurs uniformly at both sites and all over the lake, and therefore represents a periodical change in lake-water volume. The limited amount of observation data at site $\mathrm{W}$ (1 year compared to 2.5 years at site $\mathrm{C}$ ) might be responsible for the increased noise in the resulting mean daily signal and, at least in part, for the difference in the daily amplitude between both sites. Both the stacked mean daily signals (Fig. 7b) and the amplitude spectra (Fig. 4 b,c: $1 \mathrm{~d}^{-1}$ ) indicate a larger amplitude of the daily lake-level cycle at site $\mathrm{C}$ than at $\mathrm{W}$.

This periodical, daily lake-level variation is not predicted by our lake-tide model (Marderwald, 2014). The mean lake-level cycle at site $C$ lags that of the air temperature at El Calafate (grey curve in Fig. 7a) by 2 (minimum) to $3 \mathrm{~h}$ (maximum). This suggests that the daily lake-level cycle reflects periodical variations in the lake's water volume due to melt water influx from the surrounding glaciers which, in turn, is governed by the daily air temperature cycle. The entire process of ice melting, melt water percolation and run-off down to the lake is responsible for the observed lag in the lake-level response. In addition, up to about one quarter of the daily lake-level amplitude observed at site $\mathrm{C}$ might result from thermal expansion due to the daily variation in water temperature. The mean daily water temperature cycle at tide gauge $\mathrm{C}$ (water depth 1.5 $\mathrm{m}$, not shown in Fig. 7) has its maximum at 22:00 UTC, synchronous with the lake-level peak, its minimum at 12:30 UTC and an amplitude of $0.4 \mathrm{~K}$, while at site $\mathrm{W}$ (water depth $6 \mathrm{~m}$ ) only half this amplitude is observed.

The east-west wind-speed signal observed at El Calafate (Fig. 7a, dashed curve) shows a pronounced daily periodicity. Peaking approximately $2 \mathrm{~h}$ after the air temperature it manifests the effect of catabatic winds on the surrounding glaciers. The synchronicity of the peaks of wind speed and lake level suggests that wind driven water transport with daily period may contribute in addition to water mass influx from glacier melting and steric water volume changes to the observed lake-level cycle. This would explain the increase in daily lake-level amplitude observed at the downwind tide gauge $\mathrm{C}$ compared to site W. However, the uncertainty of the mean daily lake-level cycle at site $\mathrm{W}$ does at present not allow an unambiguous quantification of this contribution.

In Fig. $7 \mathrm{~b}$ the mean daily lake-level signals observed in Lago Argentino are compared to those in Lagos Fagnano and Viedma. Lago Fagnano, lacking the direct influence of glaciers, features a mean daily lake-level signal much smaller in amplitude than in Lago Argentino and characterized by two maxima and minima. The mean daily signal derived for Lago Viedma is affected by substantial noise, similar to that for site $\mathrm{W}$, suggesting that more observations are needed for a precise determination of the daily lake-level cycle in this lake. However, the inferred range of daily lake-level variation is comparable with that observed at site $\mathrm{C}$. The approximately $5 \mathrm{~h}$ lag of the lake-level peak in Lago Viedma compared to Lago Argentino might be explained as a result of the different geographical distribution (distance from the lake, orientation) of efficient melt centres at both lakes. Lakelevel variations in Lago Viedma with daily period may, by its drainage through Río La Leona, also contribute to the daily lake-level cycle in Lago Argentino.

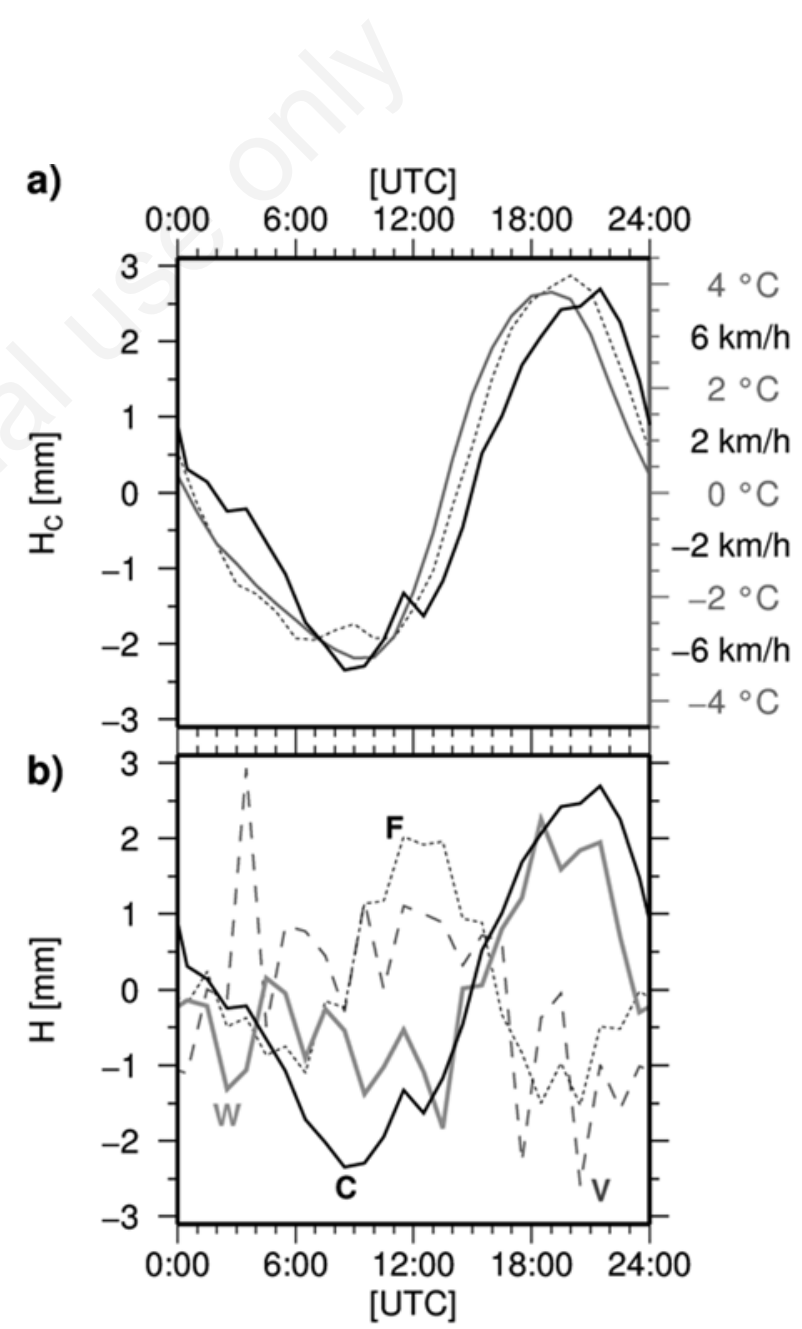

Fig. 7. a) Stacked mean daily lake-level signal observed at site $\mathrm{C}, \mathrm{H}_{\mathrm{C}}$ (black). Solid grey line: stacked mean daily air temperature signal at El Calafate (2011-2014; grey axis annotation to the right); dotted line, stacked mean daily signal in the east-west wind velocity component observed at El Calafate (black axis annotation to the right). b) Comparison of the stacked mean daily lake-level signal at site C (black) with that at site W (grey) and for Lagos Viedma (V, long dashed, BDHI, 2015) and Fagnano (F, dotted; Richter et al. 2010). 


\section{DISCUSSION}

Lake-level variations observed in Lago Fagnano have been explained to a large extend by four processes: lakevolume changes, lake-level tilt, surface seiches and lake tides (Richter et al., 2010). While the first process occurs uniformly over the entire lake, the latter three processes exhibit characteristic patterns of magnitude and sign over the lake, the areal integrals of which equal zero, and thus represent different forms of water movement within the lake.

In Lago Argentino our tide gauge records reveal a substantial contribution of three of these processes: lake-volume changes, surface seiches and lake tides. The lake-level tilt observed in Lago Fagnano represents the static response to differential air-pressure changes over the lake. The time series of differential lake-level variations between sites C and W (Fig. 2b) shows no significant correlation (correlation coefficient $\mathrm{r}=0.16$ ) with the air pressure differences between El Calafate and Río Gallegos (250 km to the ESE from Lago Argentino). This does not allow to conclude that Lago Argentino would not react statically to air pressure variations. Our two tide gauge sites are representative for the glacier-valley setting. The narrow, meandering channels do not offer sufficient surface area for an effective response to air pressure. Over the broad eastern part of the lake, however, the differential inverse barometer effect may indeed be as efficient as over Lago Fagnano. On the other hand, the large distance between the meteorological stations is not appropriate to derive air pressure gradients representative for the lake area.

Differential lake-level variations, that is, water movements between sites $\mathrm{C}$ and $\mathrm{W}$ in Lago Argentino are clearly dominated by surface seiches. The time series of differential lake- level variations yields a standard deviation of only 2.1 $\mathrm{cm}$ compared to peak seiches amplitudes exceeding $20 \mathrm{~cm}$. This demonstrates that the response of at least this part of the lake to external forcing is predominantly resonant. Wind, locally intensified by a catabatic component and favourably channelled through the narrow glacier valleys, is identified as the major driver of water movements. But also rare catastrophic events (Perito Moreno glacier burst, landslide) are shown to induce a resonant response.

Compared to Lago Fagnano the surface seiches in Lago Argentino are more intense $(20 \mathrm{~cm}$ amplitude in Lago Argentino vs $10 \mathrm{~cm}$ in Lago Fagnano), but more heavily damped. While in Lago Fagnano an exceptional seiches series of eleven days of duration (143 cycles) was observed, the seiches series in Lago Argentino hardly persist over a couple of days or a few dozens of cycles. The different damping is explained by the regular basin geometry of Lago Fagnano compared to the highly heterogeneous bathymetry of Lago Argentino. The glacier valley channels of the latter were occupied until relatively recently (Holocene, Strelin et al., 2014) by glaciers, leaving behind tall moraine ridges across the channel beds. These shallow-water barriers are today obstacles for water movement in the lake, dissipating kinetic energy of the standing waves. In fact, Punta Bandera is part of a major moraine complex (Strelin et al., 2014), predestining this location for nodes of standing waves. It is, therefore, not too surprising that seiches modes observed elsewhere are not manifested at nearby site $\mathrm{C}$. In addition, the daily recurring catabatic wind is bound to interrupt any ongoing seiches, thus impeding the development of undisturbed series as long-lasting as in Lago Fagnano.

Lake tides reach smaller amplitudes in Lago Argentino (maximum M2 amplitude: $3 \mathrm{~mm}$ ) than in Lago Fagnano $(5 \mathrm{~mm})$. This observation is consistent with a general trend of decreasing lake tide magnitude towards north as predicted by our lake tide models. This trend is opposed to the expected relationship between tidal amplitudes and the lake's areal extent (i.e., maximum amplitudes for Lago Buenos Aires/General Carrrera and Lago Argentino), but is explained by the northward decreasing load tide contribution. From north to south the investigated lakes steadily approach the Atlantic coast with its exceptionally strong ocean tides peaking between Río Gallegos and the mouth of the Magellan Strait. This makes the relative magnitude of the load tide with respect to the body tide contribution grow from roughly 1:1 in Lago Viedma to 5:1 in Lago Fagnano (Fig. 5d).

The misfit of our lake tide model is worse in Lago Argentino than in Lago Fagnano. The reason is a $23^{\circ}$ phase shift between modelled and observed signal. However, this offset is consistently reproduced also in Lago Viedma (and similarly for the S2 constituent, Fig. 5c). While the body tide contribution is regarded as well known (Richter et al., 2009; Pugh et al., 2012), the accuracy of the modelled load tide signal depends on the quality of the ocean tide model and the elastic earth model employed in modelling the ocean tidal loading effect. This is confirmed by the vectors of body tide, load tide and observed M2 tide at Laguna del Indio in Lago Fagnano (site $\mathrm{C}$ in Richter et al., 2009, 2010) included in Fig. 5d (grey). In Lago Fagnano consistency is found between the modelled body tide vector and the phase relation between modelled load tide and observed lake tides. In this lake, the mismatch between model and observation results from an underestimation of the load tide amplitude by the model. The regional validation of the ocean tide model introduced in the load tide modelling by offshore tide gauge records (Richter et al., 2012) leads to the conclusion that the roughly $20 \%$ amplification of the ocean tidal loading as revealed by the Fagnano lake tide observations are indicative for elastic mechanical properties of the lithosphere differing in this region from the adopted global earth model (Richter et al., 2009, 2011).

In Lago Argentino, in turn, the mismatch between observed and modelled M2 signal is dominated by the phase 
offset. Following the usual assumption that the body tide contribution is modelled correctly, the lake tide observations at site $\mathrm{W}$ suggest that the ocean tidal loading in the Lago Argentino region occurs some $30^{\circ}$ earlier and, in agreement with the conclusions drawn from Lago Fagnano, with an amplification of some tens of per cents in amplitude compared to the model prediction. In general, the amplitude of ocean tidal loading is more sensitive to the elastic properties of the lithosphere than the phase. Therefore, we assume that the discrepancy of the modelled load tide in Lago Argentino probably indicates in first place regional deficiencies of the ocean tide model rather than the elastic earth model. Ocean tidal loading in the Lago Argentino area is dominated by the ocean tides in the channels and fjords of the highly fragmented Pacific coast. This environment remains a challenge for global ocean tide models, even in times of satellite altimetry. Moreover, in this hardly populated coast tidal observations for validating or constraining these models are particularly sparse. An M2 phase lag of $30^{\circ}$, corresponding to approximately one hour, of the employed global ocean tide model in this region seems thus possible and to be a plausible explanation of the observed lake tide model inconsistency. We may not exclude, however, that regional differences of the rheological properties of the lithosphere from the conventional elastic earth models may also contribute in a similar way as shown for Lago Fagnano. Tide gauge observations in the Pacific coastal channels and fjords would be needed to validate existing ocean tide models in this region and to draw any conclusion about the representativeness of elastic earth models based on the load tide contribution to the lake tides observed in Lago Argentino. Such a validation of elastic earth models would be of particular value in the region of the Southern Patagonian Icefield in order to improve the determination of elastic crustal deformations due to ongoing ice mass changes and its separation from long-term visco-elastic adjustment (Lange et al., 2014; Dietrich et al., 2010).

Lake-volume changes are in Lago Argentino of much larger magnitude and more complex than in Lago Fagnano. The principal reason for this is the immediate vicinity of Lago Argentino, as well as Lago Viedma draining into the former, to the glaciers descending from the Southern Patagonian Icefield. The amplitude of the annual lake-level cycle in Lago Argentino is $1.2 \mathrm{~m}$ compared to $21 \mathrm{~cm}$ in Lago Fagnano. The annual signal in Lago Argentino lags that of Lago Fagnano by two (minimum) to three (maximum) months. The time shift in the lake-level maximum is likely due to the melt water contribution from the glaciers surrounding Lago Argentino. In addition to the annual cycle, lake-volume changes in Lago Argentino are characterized by a periodical daily signal and by sporadic events of rapid water influx due to bursting of the Perito Moreno glacier ice dam. Neither of these phenomena are observed in Lago Fagnano.
The comparative juxtaposition of Lago Argentino and Lago Fagnano with respect to the processes affecting their lake levels allows a tentative extrapolation to the other great Patagonian lakes. The differences in the lake-level variations in Lagos Argentino and Fagnano can be related to their morphological and geometrical characteristics. Lakes, or parts of lakes, dominated by the glacier-valley environment (e.g., Lago San Martín/O'Higgins) most likely tend to a resonant response to external forcing, especially wind. These water movements are concentrated in isolated events rather than occurring continuously. Singular, catastrophic events, such as the landslide in Brazo Upsala, are more likely to occur in this environment. Strong fluctuations in the lake-volume, coupled to glacier melting, can be expected. In lakes representing the terminal-lake environment (e.g., Lago Viedma) the static response to external forcing (e.g., air pressure changes) will gain importance. Surface seiches are probably less effective and restricted to very few modes, possibly developed as rotational circulations such as Kelvin waves. Evaporation and other slow processes will gain in influence over the lake-volume variations. The annual maximum and minimum of lake-water volume may occur earlier in the year if there is no immediate influence from glacier melting. Independent from the geometric characteristics of the lakes, the magnitude and patterns of lake tides are predicted (Tab. 2) suggesting optimum sites for future lake-tide observations.

Lago Argentino, but also Lagos San Martín/O’Higgins and Viedma, are promising candidates for future long-term tide gauge operation in order to monitor secular lake-level changes and relative crustal deformation. Precise long-term lake-level records may provide a useful observable to validate models of glacial-isostatic adjustment in the region of the Southern Patagonian Icefield (Lange et al., 2014). The experience with the lake-level record at site $\mathrm{E}$ has taught that great care is to be taken to warrant a stable height of the tide gauge. Furthermore, at least two tide gauges should be operated simultaneously in order to separate secular relative crustal uplift from lake-volume fluctuations and water movements. Ideally, one tide gauge should be installed close to the lake's outlet at its eastern shore, while the second instrument should be deployed at a site of maximum predicted uplift. The model presented by Lange et al. (2014) predicts a relative uplift rate of $12 \mathrm{~mm} / \mathrm{a}$ for the head of Brazo Upsala with respect to the eastern lake shore. Finally, our results qualify site $\mathrm{C}$, only marginally affected by water movements, as ideal location for a long-term monitoring of the lake's hydrological balance.

\section{CONCLUSIONS}

Pressure tide gauge records at two sites provide novel insights into the lake-level variations in Lago Argentino. The processes identified in the lake-level records comprise annual, daily and rapid lake-volume changes, surface se- 
iches, lake tides and water movements induced by singular events. Our results show that lake-volume changes (annual amplitude $1.2 \mathrm{~m}$ ) and surface seiches (maximum observed amplitude $20 \mathrm{~cm}$ ) reach larger magnitudes in Lago Argentino than in Lago Fagnano. The comparison of our findings with previous results from Lago Fagnano leads to a tentative prediction of characteristics of lake-level variations in the other great Patagonian lakes.

Lake-level data from sites E, R and Lagos Viedma, San Martín/O'Higgins, Buenos Aires/General Carrera (BDHI, 2015) have proven a valuable complement of our pressure tide gauge records for the analysis of the annual lake-level cycle (Fig. 3b). A more detailed documentation of these data sets would allow an even greater benefit from this wealth of observational data. For the investigation of hydrodynamic processes, however, dedicated high-resolution tide-gauge records, as presented here, are still essential. Doubts about the stability of the height reference of the lake-level data from site $\mathrm{E}$, raised by the presented analysis, affect also the confidence in the conclusions on secular lake-level trends derived previously by other authors from this data set (Pasquini and Depetris, 2011).

\section{ACKNOWLEDGMENTS}

We are grateful to Luis Barbero, Carlos Ferrer, Mathias Fritsche and Lautaro Simontacchi for their valuable help in the fieldwork. We thank Pref. Ppal. José Luis Sartori and the staff at Prefectura Naval Lago Argentino, El Calafate, for their logistic support of the lake operations.

We thank Silvina Sturzenbaum from the Administration of Parque Nacional Los Glaciares for support, advice and permission for our activities in the National Park. Part of the lake-level data were retrieved from the Base de Datos Hidrológicos Integrada (BDHI, 2015) maintained by the Argentine Subsecretaría de Recursos Hídricos. We thank the Argentine Servicio Meteorológico Nacional for the provision of meteorological data from stations El Calafate and Río Gallegos. The fieldwork was partly funded by the German Research Foundation DFG under project RI-2340/1-1. We thank the three anonymous reviewers for their constructive comments.

\section{REFERENCES}

BDHI, 2015. Base de Datos Hidrológica Integrada. Accessed on: January 2015. Avaiulable from: http://bdhi.hidricosargentina.gov.ar/sitioweb/frmFiltro.aspx

Bell C, Vassie JM, Woodworth PL, 1998. TASK-2000 Tidal Analysis Software Kit. PSMSL/Proudman Oceanographic Laboratory, Bidston Observatory, Birkenhead, UK.

Busch P, 2014. [Bestimmung von Höhe und Geometrie pleistozäner Seeterrassen des Lago Argentino (Patagonien) zur Nutzung als Indikatoren für Krustende- formationen].[Unpublished MSc Thesis in German]. Technische Universität Dresden, Germany.
Casassa G, Rivera A, 1999. Topografic mass balance model for the Southern Patagonian Icefield, p. 44. Proc. Int. Symp. Verification of Cryospheric models, Bringing Data and Modeling Scientists Together, Zürich, Switzerland.

Del Cogliano D, Dietrich R, Richter A, Perdomo R, Hormaechea JL, Liebsch G, Fritsche M, 2007. Regional geoid determination in Tierra del Fuego including GPS levelling. Geologica Acta 5:315-322.

Diaz M, Pedrozo F, Reynolds C, Temporetti P, 2007. Chemical composition and the nitrogen- regulated trophic state of Patagonian lakes. Limnologica 37:17-27.

Dietrich R, Ivins E, Casassa G, Lange H, Wendt J, Fritsche M, 2010. Rapid crustal uplift in Patagonia due to enhanced ice loss. Earth Planet. Sci. Lett. 289:22-29.

Farrell W, 1972. Deformation of the Earth by surface loads. Rev. Geophy. Space Phys. 10:761-797.

Forel FA, 1895. [Le Léman; monographie limnologique. 2].[Book in French]. F. Rouge, Lausanne: 651 pp.

Fosdick JC, Romans BW, Fildani A, Bernhardt A, Calderón M, Graham SA, 2011. Kinematic evolution of the Patagonian retroarc fold-and-thrust belt and Magallanes foreland basin, Chile and Argentina, $51^{\circ} 30^{\prime} \mathrm{S}$. Geol. Soc. Amer. Bull. 123:1679-1698.

Ghiglione MC, Suarez F, Ambrosio A, Da Poian G, Cristallini EO, Pizzio MF, Reinoso RM, 2009. Structure and evolution of the Austral Basin fold-thrust belt, southern Patagonian Andes. Rev. As. Geol. Argentina 65:215-226.

Kobayashi S, Naruse R, Skvarca P, Sato T, 2001. Calving activities of Perito Moreno Glacier, southern Patagonia, pp. 145152. In: M. Aniya and R. Naruse (eds.), Glaciological and geomorphological studies in Patagonia, 1998 and 1999.

Lange H, Casassa G, Ivins E, Schröder L, Fritsche M, Richter A, Groh A, Dietrich R, 2014. Observed crustal uplift near the Southern Patagonian Icefield constrains improved viscoelastic Earth models. Geophys. Res. Lett. 41:805-812.

Lodolo E, Menichetti M, Bartole R, Ben-Avraham Z, Tassone A, Lippai H, 2003. Magallanes- Fagnano continental transform fault. Tectonics 22:1076-1103.

Marderwald ER, 2014. [Modelado de las mareas de grandes lagos patagónicos].[Unpublished Thesis in Spanish]. Universidad Nacional de La Plata, Argentina.

Mendoza L, Perdomo R, Hormaechea JL, Del Cogliano D, Fritsche M, Richter A, Dietrich R, 2011. Present-day crustal deformation along the Magallanes-Fagnano Fault System in Tierra del Fuego from repeated GPS observations. Geophys. J. Int. 184:1009-1022.

Mendoza L, Richter A, Fritsche M, Hormaechea JL, Perdomo R, Dietrich R, 2015. Block modeling of crustal deformation in Tierra del Fuego from GNSS velocities. Tectonophysics 651-652:58-65.

Menichetti M, Lodolo E, Tassone A, 2008. Structural geology of the Fuegian Andes and Magallanes fold-and-thrust belt Tierra del Fuego Island. Geologica Acta 6:19-42.

Mortimer CH, 1974. Lake hydrodynamics. Mitt. Internat. Verein. Limnol. 20:124-197.

Naruse R, Skvarca P, 2000. Dynamic features of thinning and retreating Glaciar Upsala, a lacutrine calving glacier in southern Patagonia. Arct. Antarct. Alp. Res. 32:485-491.

Pasquini AI, Depetris PJ, 2011. Southern Patagonia's Perito Moreno Glacier, Lake Argentino, and Santa Cruz River hy- 
drological system: an overview. J. Hydrol. 405:48-56.

Pasquini AI, Lecomte KL, Depetris PJ, 2008. Climate change and recent water level variability in Patagonian proglacial lakes, Argentina. Global Planet. Change 63:290-298.

Pavlis NK, Holmes SA, Kenyon SC, Factor JK, 2012. The development and evaluation of the Earth Gravitational Model 2008 (EGM2008). J. Geophys. Res. 117: B04406.

Pugh DT, Woodworth PL, Bos MS, 2011. Lunar tides in Loch Ness, Scotland. J. Geophys. Res. 116:C11040.

Quirós R, Baigún CRM, Cuch S, Delfino R, De Nichilo A, Guerrero C, Marinone MC, Menu Marque S, Scapini MC, 1988. [Evaluación del Rendimiento Pesquero Potencial de la República Argentina: I. Datos 1].[Report in Spanish]. Informe Técnico No. 7 del Departamento de Aguas Continentales. Instituto Nacional de Investigación y Desarrollo Pesquero, Mar del Plata: 55 pp.

Rabassa J, Coronato AM, Salemme M, 2005. Chronology of the Late Cenozoic Patagonian glaciations and their correlation with biostratigraphic units of the Pampean region (Argentina). J. South American Earth Sci. 20:81-103.

Richter A, Hormaechea JL, Dietrich R, Perdomo R, Fritsche M, Del Cogliano D, Liebsch G, Mendoza L, 2009. Anomalous ocean load tide signal observed in lake-level variations in Tierra del Fuego. Geophys. Res. Lett. 36:L05305.

Richter A, Hormaechea JL, Dietrich R, Perdomo R, Fritsche M, del Cogliano D, Liebsch G, Mendoza L, 2010. Lake-level variations of Lago Fagnano, Tierra del Fuego: observations, modelling and interpretation. J. Limnol. 69:29-41.

Richter A, Hormaechea JL, Perdomo R, Mendoza L, Del Cogliano D, Fritsche M, Scheinert M, Dientrich R, 2011. Ocean tidal loading effects in Tierra del Fuego (Argentina): observations and modelling. Geophys. Res. Abstr. 13: EGU2011-4317.

Richter A, Marcos M, Monserrat S, Gomis D, Ruiz S, Liebsch G, Dietrich R, 2005. Comparison and combination of coastal and off-shore tide gauge measurements from Eivissa Island, Western Mediterranean. Mar. Geod. 28:271-289.

Richter A, Mendoza L, Perdomo R, Hormaechea JL, Savcenko R, Bosch W, Dietrich R, 2012. Pressure tide gauge records from the Atlantic shelf off Tierra del Fuego, southernmost South America. Cont. Shelf Res. 42:20-29 .

Savcenko R, Bosch W, 2008. EOT08a - Empirical Ocean Tide Model from Multi-mission Satellite Altimetry. DGFI Report No. 81. Deutsches Geodätisches Forschunsginstitut (DGFI), München.

Skvarca P, De Angelis H, 2001. Bathymetric survey in the vicinity of calving Glacier Upsala, Lago Argentino, southern Patagonia, Argentina, pp. 131-140. In: M. Aniya and R. Naruse (eds.), Glaciological and geomorphological studies in Patagonia, 1998 and 1999.

Strelin JA, Kaplan MR, Vandergoes MJ, Denton GH, Schaefer JM, 2014. Holocene glacier history of the Lago Argentino basin, Southern Patagonian Icefield. Quatern. Sci. Rev. 101:124-145.

Sugiyama S, Skvarca P, Naito N, Enomoto H, Tsutaki S, Tone K, Marinsek S, Aniya M, 2011. Ice speed of a calving glacier modulated by small fluctuations in basal water pressure. Nat. Geosci. 4:597-600.

Weischet, W, 1996. [Regionale Klimatologie, Teil 1. Die Neue Welt: Amerika - Neuseeland - Australien].[Book in German]. Teubner Verlag, Stuttgart: 468 pp. 